\title{
FAKTOR-FAKTOR YANG MEMPENGARUHI KUALITAS HIDUP PASIEN GAGAL GINJAL KRONIK (GGK) YANG MENJALANI TERAPI HEMODIALISA DI RSU ROYAL PRIMA MEDAN
}

\section{Factors Affecting of Quality of Life of Chronic Kidney Disease (CKD) Patients that Undergo Hemodialysis Therapy in Royal Prima Hospital Medan}

\author{
Yona Sarastika $^{1}$, Kisan $^{2}$, Opirisnawati Mendrofa ${ }^{3}$, Juwita Verawati Siahaan ${ }^{4}$ \\ ${ }^{1,2,3}$ Mahasiswa S1 Keperawatan, FKK Universitas Prima Indonesia Medan \\ Email : sarastikayona@gmail.com, kisangayo@gmail.com, \\ opirisnawatimendrofa10@gmail.com, \\ ${ }^{4}$ Dosen Tetap FKK Universitas Prima Indonesia Medan \\ Email: verawatijuwita@yahoo.com
}

DOI : https://doi.org/10.34008/jurhesti.v4i1.93

\begin{abstract}
Abstrak
Gagal Ginjal Kronik merupakan proses dimana ginjal lambat laun mulai tidak dapat melakukan fungsinya dalam rentang waktu lebih dari tiga bulan. World Health Organization (WHO) atau Badan Kesehatan Dunia secara global mengatakan pertumbuhan jumlah penderita gagal ginjal kronik pada tahun 2013 di dunia meningkat sebesar 50\% dari tahun sebelumnya, pada tahun 2014 di Amerika penderita gagal ginjal kronik meningkat sebesar 50\% dan setiap tahun ada sekitar 200.000 orang di Amerika menjalani hemodialisis. Tujuan penelitian adalah untuk mengetahui faktor-faktor yang mempengaruhi kualitas hidup pasien gagal ginjal kronik yang menajalani terapi hemodialisa di RSU Royal Prima Medan tahun 2019. Jenis penelitian yang digunakan adalah penelitian analitik deskriptif dengan pendekatan Cross Sectional. Populasi dalam penelitian sebanyak 70 orang, sampel sebanyak 70 orang dengan teknik total sampling. Hasil penelitian menunjukkan tidak ada hubungan umur dengan kualitas hidup pasien gagal ginjal kronik yang menjalani terapi hemodialisa ( $\mathrm{p}$ value $=0,910>0,05$ ), tidak ada hubungan jenis kelamain dengan kualitas hidup ( $\mathrm{p}$ value $=0,599>0,05$ ), tidak ada hubungan pendidikan dengan kualitas hidup ( $\mathrm{p}$ value $=0,943>0,05)$, ada hubungan lamanya hemodialisa dengan kualitas hidup ( $\mathrm{p}$ value $=$ $0,001<0,05)$. Diharapkan bagi pasien untuk mematuhi terapi hemodialisa agar tercapai kualitas hidup yang baik.
\end{abstract}

Kata Kunci: gagal ginjal kronik, kualitas hidup, hemodialisa

\begin{abstract}
Chronic Kidney Disease is a process where the kidney gradually become out of function in more than three months. World Health Organization (WHO) states that the growth of chronic kidney disease sufferers globally in 2013 increased up to 50\% from the previous year, in 2014, chronic kidney disease sufferers in United States of America increased up to 50\% and every year that are approximately 200.000 people in United States of America undergoing hemodialysis. The objective of this study is to identify factors affecting the quality of life of chronic kidney disease patients that undergo hemodialysis therapy in Royal Prima Medan Hospital in 2019. This study uses descriptive analytic study with Cross Sectional approach. The population in this study are 70 people, and 70 people as samples with total sampling technique. The result of this study shows that there is no connection between age and the quality of life of chronic kidney disease patients that undergo hemodialysis therapy ( $p$ value $=0,910>0,05$ ), no connection between gender and quality of life ( $p$ value $=0,599>0,05)$, no connection between education background and quality of life ( $\mathrm{p}$ value $=0,943>0,05$ ), and there is a connection between the duration of hemodialysis with quality of life $(\mathrm{p}$ value $=0,001<0,05)$. The patients are expected to obey the hemodialysis therapy in order to achieve a good quality of life.
\end{abstract}

Keywords: chronic kidney disease, quality of life, hemodialysis

\section{PENDAHULUAN}

Gagal Ginjal Kronik merupakan proses dimana ginjal lambat laun mulai tidak dapat melakukan fungsinya dalam rentang waktu lebih dari tiga bulan. Gagal Ginjal Kronik dapat menimbulkan simtoma, yaitu laju filtrasi glomerular berada dibawah $60 \mathrm{ml} / \mathrm{men} / 1.73 \mathrm{~m}^{2}$, atau diatas 
nilai tersebut yang disertai dengan kelainan sedimen urine. Selain itu, adanya batu ginjal juga dapat menjadi indikasi gagal ginjal kronik pada penderita kelainan bawaan, seperti hioeroksaluria dan sistinuria (Muhammad, 2012).

World Health Organization (WHO) atau Badan Kesehatan Dunia secara global mengatakan pertumbuhan jumlah penderita gagal ginjal kronik pada tahun 2013 di dunia meningkat sebesar $50 \%$ dari tahun sebelumnya, pada tahun 2014 di Amerika penderita gagal ginjal kronik meningkat sebesar $50 \%$ dan setiap tahun ada sekitar 200.000 orang di Amerika menjalani hemodialisis (Widyastuti, 2014).

Peneliti Deddy (2015) menyatakan bahwa faktor-faktor yang mempengaruhi kualitas hidup pasien gagal ginjal kronik yang menjalani hemodialisa di RSUP HAM Medan terdiri dari faktor status nutrisi, kondisi komorbid, lama menjalani hemodialisa dan penatalaksanaan medis. Di lihat dari persentase karakteristik responden dengan nilai tertinggi berdasarkan usia adalah beumur 56-70 tahun berjumlah 16 orang $(50 \%)$ dari 32 sampel, jenis kelamin laki-laki berjumlah 23 orang (71,9\%), berdasarkan status pernikahan persentase tertinggi yaitu yang sudah menikah berjumlah 29 orang $(90,6 \%)$, berdasarkan jenjang pendidikan persentase tertinggi yaitu perguruan tinggi berjumlah 16 orang $(50 \%)$, berdasarkan pekerjaan persentase tertinggi yaitu bekerja sebagai wiraswasta berjumlah 11 orang $(34,4 \%)$, berdasarkan penghasilan persentase tertinggi yaitu berpenghasilan Rp. $1.200 .000-\mathrm{Rp}$. $1.800 .000 /$ bulan berjumlah 14 orang $(43,8 \%)$, berdasarkan penyakit persentase tertinggi yaitu non-DM berjumlah 25 orang $(78,1 \%)$.

Berdasarkan penelitian Handi dkk (2018) di RSUD dr M.Yunus Bengkulu menyatakan bahwa faktor-faktor yang mempengaruhi kualitas hidup pasien gagal ginjal kronik yang menjalani hemodialisa yang pertama adalah usia sebanyak $85,1 \%$ memiliki usia <20->35 tahun, kedua berdasarkan jenis kelamin prevalensi jenis kelamin perempuan lebih tinggi dibandingkan laki-laki 61,2 \%, ketiga berdasarkan penghasilan didapatkan lebih dari sebagaian $59,7 \%$ berpenghasilan cukup/lebih, keempat berdasarkan tingkat depresi hampir sebagian responden 34,3\% memiliki kategori normal, kelima berdasarkan dukungan keluarga didapatkan lebih dari sebagian $64,2 \%$ memiliki dukungan keluarga baik, yang terakhir berdasarkan kualitas hidup pasien diketahui lebih dari sebagian 50,7\% memiliki kualitas hidup tinggi.

Berdasarkan hasil survey awal yang dilakukan peneliti pada bulan 8 April 2019 diperoleh data bahwa penderita gagal ginjal kronik yang menjalani hemodialisa di RSU Royal Prima Medan Tahun 2019 sebanyak 70 orang. Selain itu, peneliti melakukan wawancara dengan 5 orang pasien gagal ginjal kronik yang menjalani hemodialisa mengatakan penurunan kualitas hidup yang dirasakan dalam segi fisik, psikologis, sosial dan lingkungan. Pasien mengatakan sudah tidak mampu lagi bekerja seperti dulu akibat kondisinya saat ini.

Berdasarkan uraian dari latar belakang diatas, peneliti tertarik untuk melakukan penelitian tentang "FaktorFaktor Yang Mempengaruhi Kualitas Hidup Pasien Gagal Ginjal Kronik (GGK) yang Menjalani Terapi Hemodialisa di RSU Royal Prima Medan Tahun 2019”.

\section{METODE}

Jenis penelitian yang digunakan adalah penelitian analitik deskriptif dengan pendekatan Cross Sectional. Lokasi penelitian di RSU Royal Prima Medan. Populasi penelitian adalah semua pasien gagal ginjal kronik (GGK) yang menjalani terapi hemodialisa di RSU Royal Prima Medan tahun 2019. Teknik pengambilan sampel menggunakan total sampling sebanyak 70 orang responden. Pengambilan data dilakukan dengan menggunaan kuesioner WHOQOL-BREF untuk mengukur kualitas hidup. Analisis data menggunakan analisis univariat dan analisis bivariat menggunakan uji chi-squae. 
HASIL PENELITIAN

Analisa Univariat

Berdasarkan hasil penelitian Faktor-

Faktor yang Mempengaruhi Kualitas Hidup Pasien Gagal Ginjal Kronik (GGK) Yang
Menjalani Terapi Hemodialisa di RSU Royal Prima Medan Tahun 2019, dapat dilihat gambaran distribusi frekuensi sebagai berikut:

Tabel 1. Distribusi Frekuensi Responden Berdasarkan Faktor-Faktor Yang Mempengaruhi Kualitas Hidup Pasien Gagal Ginjal Kronik (GGK) Yang Menjalani Terapi Hemodialisa di RSU Royal Prima Medan Tahun 2019

\begin{tabular}{|c|c|c|}
\hline No. Variabel & Frekuensi (n) & Persentase (\%) \\
\hline 1. Usia & & \\
\hline a. $15-24$ & 1 & 1,5 \\
\hline b. $25-34$ & 7 & 10 \\
\hline c. $35-44$ & 10 & 14,3 \\
\hline d. $45-54$ & 18 & 24,3 \\
\hline e. $55-64$ & 26 & 38,5 \\
\hline f. $65-74$ & 8 & 11,4 \\
\hline g. $>75$ & 0 & 0 \\
\hline Total & 70 & 100 \\
\hline 2. Jenis Kelamin & & \\
\hline a. Laki-Laki & 41 & 58,5 \\
\hline b. Perempuan & 29 & 41,5 \\
\hline Total & 70 & 100 \\
\hline Pendidikan & & \\
\hline a. SD & 0 & 0 \\
\hline b. SMP & 6 & 8,6 \\
\hline c. SMA & 42 & 60 \\
\hline d. PT & 22 & 31,4 \\
\hline Total & 70 & 100 \\
\hline Lama Hemodialisa & & \\
\hline a. $1-12$ & 33 & 47,1 \\
\hline b. $13-24$ & 20 & 28,6 \\
\hline c. $25-36$ & 9 & 12,9 \\
\hline d. $37-48$ & 5 & 7,1 \\
\hline e. $49-60$ & 3 & 4,3 \\
\hline f. $>60$ & 0 & 0 \\
\hline Total & 70 & 100 \\
\hline $\begin{array}{ll}\text { 5. } & \text { Kualitas Hidup }\end{array}$ & & \\
\hline a. Sangat Buruk & 0 & 0 \\
\hline b. Buruk & 0 & 0 \\
\hline c. Sedang & 33 & 47,1 \\
\hline d. Baik & 36 & 51,4 \\
\hline e. Sangat Baik & 1 & 1,5 \\
\hline Total & 70 & 100 \\
\hline
\end{tabular}

Berdasarkan tabel 1 di atas menunjukkan bahwa dari 70 responden ditinjau dari umur terdapat mayoritas responden berumur 55-64 tahun sebanyak 26 orang $(37,1 \%)$ dan minoritas berumur 15 24 tahun sebanyak 1 orang (1,5\%). Ditinjau dari jenis kelamin mayoritas berjenis kelamin laki-laki sebanyak 41 orang $(58,5 \%)$ dan minoritas berjenis kelamin perempuan sebanyak 29 orang $(41,5 \%)$.
Ditinjau dari pendidikan mayoritas berpendidikan SMA sebanyak 42 orang (60\%) dan minoritas pendidikan SMP sebanyak 6 orang $(8,6 \%)$. Ditinjau dari lamanya hemodialisa mayoritas $1-12$ bulan sebanyak 33 orang $(47,1 \%)$, dan minoritas lamanya hemodialisa 49-60 bulan sebanyak 3 orang $(4,3 \%)$. Ditinjau dari kualitas hidup mayoritas kualitas hidup baik sebanyak 36 orang $(51,4 \%)$ dan minoritas kualitas hidup sangat baik sebanyak 1 orang $(1,5 \%)$. 


\section{Analisa Bivariat}

Analisa Bivariat dilakukan untuk melihat faktor-faktor yang mempengaruhi kualitas hidup pasien gagal ginjal kronik
(GGK) yang menjalani terapi hemodialisa di RSUD Royal Prima Medan Tahun 2019, maka diperoleh sebagai berikut:

Tabel 2. Distribusi Frekuensi Umur Yang Mempengaruhi Kualitas Hidup Pasien Gagal Ginjal Kronik (GGK) Yang Menjalani Terapi Hemodialisa di RSU Royal Prima Medan Tahun 2019

\begin{tabular}{|c|c|c|c|c|c|c|c|c|c|c|}
\hline \multirow{3}{*}{ Umur } & \multicolumn{6}{|c|}{ Kualitas Hidup } & \multirow{2}{*}{\multicolumn{2}{|c|}{ Total }} & \multirow{3}{*}{ df } & \multirow{3}{*}{ p value } \\
\hline & \multicolumn{2}{|c|}{ Sedang } & \multicolumn{2}{|c|}{ Baik } & \multicolumn{2}{|c|}{ Sangat Baik } & & & & \\
\hline & $\mathbf{n}$ & $\%$ & $\mathbf{n}$ & $\%$ & $\mathbf{n}$ & $\%$ & $\mathbf{N}$ & $\%$ & & \\
\hline $15-24$ & 3 & 75 & 1 & 25 & - & - & 4 & 100 & 10 & 0,910 \\
\hline $25-34$ & 3 & 42,9 & 4 & 57,1 & - & - & 7 & 100 & & \\
\hline $35-44$ & 9 & 56,2 & 7 & 43,8 & - & - & 16 & 100 & & \\
\hline $45-54$ & 14 & 60,9 & 9 & 39,1 & - & - & 23 & 100 & & \\
\hline $55-64$ & 4 & 25 & 11 & 68,8 & 1 & 6,2 & 16 & 100 & & \\
\hline $65-74$ & - & - & 4 & 100 & - & - & 4 & 100 & & \\
\hline
\end{tabular}

Berdasarkan tabel 2 di atas diketahui bahwa hasil uji chi-square maka didapatnilai $\mathrm{p}$ value 0,910>0,05 maka Ho diterima Ha ditolak. Kesimpulannya adalah tidak ada hubungan umur dengan kualitas hidup pasien gagal ginjal kronik (GGK) yang menjalani terapi hemodialisa di RSU Royal Prima Medan Tahun 2019.

Tabel 3. Distribusi Frekuensi Jenis Kelamin Yang Mempengaruhi Kualitas Hidup Pasien Gagal Ginjal Kronik (GGK) yang Menjalani Terapi Hemodialisa di RSU Royal Prima Medan Tahun 2019.

\begin{tabular}{|c|c|c|c|c|c|c|c|c|c|c|}
\hline \multirow{3}{*}{ Jenis Kelamin } & \multicolumn{6}{|c|}{ Kualitas Hidup } & \multirow{2}{*}{\multicolumn{2}{|c|}{ Total }} & \multirow{3}{*}{ df } & \multirow{3}{*}{$p$ value } \\
\hline & \multicolumn{2}{|c|}{ Sedang } & \multicolumn{2}{|c|}{ Baik } & \multicolumn{2}{|c|}{ Sangat Baik } & & & & \\
\hline & $\mathbf{n}$ & $\%$ & $\mathbf{n}$ & $\%$ & $\mathbf{n}$ & $\%$ & $\mathbf{N}$ & $\%$ & & \\
\hline Laki-Laki & 18 & 43,9 & 22 & 53,7 & 1 & 2,4 & 41 & 100 & 2 & 0,599 \\
\hline Perempuan & 15 & 51,7 & 14 & 48,3 & - & - & 29 & 100 & & \\
\hline
\end{tabular}

Berdasarkan tabel 3 di atas diketahui bahwa hasil uji chi-square maka didapat nilai $\mathrm{p}$ value $0,599>0,05$ maka $\mathrm{H}_{\mathrm{o}}$ diterima $\mathrm{H}_{\mathrm{a}}$ ditolak. Kesimpulannya adalah tidak ada hubungan jenis kelamin dengan kualitas hidup pasien gagal ginjal kronik (GGK) yang menjalani terapi hemodialisa di RSU Royal Prima Medan Tahun 2019.

Tabel 4. Distribusi Frekuensi Pendidikan Yang Mempengaruhi Kualitas Hidup Pasien Gagal Ginjal Kronik (GGK) Yang Menjalani Terapi Hemodialisa di RSU Royal Prima Medan Tahun 2019.

\begin{tabular}{|c|c|c|c|c|c|c|c|c|c|c|}
\hline \multirow{3}{*}{ Pendidikan } & \multicolumn{6}{|c|}{ Kualitas Hidup } & \multirow{2}{*}{\multicolumn{2}{|c|}{ Total }} & \multirow{3}{*}{ df } & \multirow{3}{*}{ p value } \\
\hline & \multicolumn{2}{|c|}{ Sedang } & \multicolumn{2}{|c|}{ Baik } & \multicolumn{2}{|c|}{ Sangat Baik } & & & & \\
\hline & $\mathbf{n}$ & $\%$ & n & $\%$ & $\mathbf{n}$ & $\%$ & $\mathbf{N}$ & $\%$ & & \\
\hline SMP & 3 & 50 & 3 & 50 & - & - & 6 & 100 & 4 & 0,943 \\
\hline SMA & 19 & 45,2 & 22 & 52,4 & 1 & 2,4 & 42 & 100 & & \\
\hline PT & 11 & 50 & 11 & 50 & - & - & 22 & 100 & & \\
\hline
\end{tabular}

Berdasarkan tabel 4 di atas diketahui bahwa hasil uji chi-square maka didapat nilai $\mathrm{p}$ value 0,943> 0,05 maka Ho diterima Ha ditolak. Kesimpulannya adalah tidak ada hubungan pendidikan dengan kualitas hidup pasien gagal ginjal kronik (GGK) yang menjalani terapi hemodialisa di RSU Royal Prima Medan tahun 2019. 
Tabel 5. Distribusi Frekuensi Lamanya Hemodialisa Yang Mempengaruhi Kualitas Hidup Pasien Gagal Ginjal Kronik (GGK) Yang Menjalani Terapi Hemodialisa di RSU Royal Prima Medan Tahun 2019

\begin{tabular}{|c|c|c|c|c|c|c|c|c|c|c|}
\hline \multirow{3}{*}{ Lamanya HD } & \multicolumn{6}{|c|}{ Kualitas Hidup } & \multirow{2}{*}{\multicolumn{2}{|c|}{ Total }} & \multirow{3}{*}{ df } & \multirow{3}{*}{ p value } \\
\hline & \multicolumn{2}{|c|}{ Sedang } & \multicolumn{2}{|c|}{ Baik } & \multicolumn{2}{|c|}{ Sangat Baik } & & & & \\
\hline & $\mathbf{n}$ & $\%$ & $\mathbf{n}$ & $\%$ & n & $\%$ & $\mathbf{N}$ & $\%$ & & \\
\hline $1-12$ & 17 & 51,5 & 16 & 48,5 & - & - & 33 & 100 & 8 & 0,001 \\
\hline $13-24$ & 6 & 30 & 14 & 70 & - & - & 20 & 100 & & \\
\hline $25-36$ & 6 & 66,7 & 3 & 33,3 & - & - & 9 & 100 & & \\
\hline $37-48$ & 3 & 60 & 2 & 40 & - & - & 5 & 100 & & \\
\hline $49-60$ & 1 & 33,3 & 1 & 33,3 & 1 & 33,4 & 3 & 100 & & \\
\hline
\end{tabular}

Berdasarkan tabel 5 di atas diketahui bahwa hasil uji chi-square maka didapat nilai $\mathrm{p}$ value $0,001<0,05{\text { maka } \mathrm{H}_{\mathrm{o}}}$ ditolak $\mathrm{H}_{\mathrm{a}}$ diterima. Kesimpulannya adalah ada hubungan lamanya hemodialisa dengan kualitas hidup pasien gagal ginjal kronik (GGK) yang menjalani terapi hemodialisa di RSU Royal Prima Medan Tahun 2019.

\section{PEMBAHASAN}

Hasil penelitian faktor-faktor yang mempengaruhi kualitas hidup pasien gagal ginjal kronik (GGK) yang menjalani terapi Hemodialisa di RSU Royal Prima Medan Tahun 2019 maka diketahui :

1. Hubungan umur dengan kualitas hidup pasien gagal ginjal kronik (GGK) yang menjalani terapi hemodialisa di RSU Royal Prima Medan Tahun 2019.

Hasil penelitian dengan menggunakan uji chi-square diperoleh bahwa nilai $\mathrm{p}$ value $0,910>0,05$ yang berarti tidak ada hubungan umur dengankualitas hidup pasien gagal ginjal kronik (GGK) yang menjalani terapi hemodialisa di RSU Royal Prima Medan Tahun 2019.

Semakin bertambahnnya umur seseorang maka terjadi penurunan fungsi ginjal, ginjal menjadi kurang kemampuannya. Bahwa pada usia 40 tahun akan terjadi penuruan laju filtrasi glomerulus, dan akhirnya berdampak terjadinya gagal ginjal kronik. (Nurcahayati (2010)

Fitri (2015) mengemukkan bahwa kualitas hidup seseorang lebih cenderung dipengaruhi oleh responden yang berusia lanjut. Sedangkan menurut Handy dkk (2018) mengemukan bahwa suatu penyakit dapat menyerang pada semua golongan umur, tergantung dari tingkat terpaparnya seperti: faktor pekerjaan, kebiasaan hidup, dan penyalahgunaan obat.Hal ini sejalan dengan penelitian Nurcahayati (2010) bahwa pada hakikatnya kualitas hidup pada gagal ginjal kronik yang menjalani terapi hemodialisa tidak di pengengaruhi oleh umur, karena semua golongan umur mempunyai risiko untuk terkena penyakit.

Menurut asumsi peneliti bahwa umur tidak mempengaruhi kualitas hidup pasien gagal ginjal kronik (GGK) yang menjalani terapi hemodialisa di RSU Royal Prima Medan Tahun 2019. Hal ini disebebkan karena suatu penyakit dapat menyerang setiap orang pada semua golongan umur.

2. Hubungan jenis kelamin dengan kualitas hidup pasien gagal ginjal kronik (GGK) yang menjalani terapi hemodialisa di RSU Royal Prima Medan Tahun 2019

Hasil penelitian dengan menggunakan uji chi-square maka didapat nilai $\mathrm{p}$ value $0,599>0,05$ yang berarti tidak ada hubungan jenis kelamin terhadapat kualitas hidup pasien gagal ginjal kronik (GGK) yang menjalani terapi hemodialisa di RSU Royal Prima Medan tahun 2019. Dengan persentase yang berjenis kelamin laki-laki lebih banhyak menjalani hemodialisa dibandingkan perempuan yaitu sebanyak 41 orang $(58,5 \%)$.

Pada pasien gagal ginjal kronik yang menjalani terapi hemodialisa tidak dipengaruhi oleh jenis kelamin, antara laki- 
laki dan perempuan. Keduanya memiliki resiko yang sama untuk menderita penyakit gagal ginjal kronik. Pada umumnya penyakit gagal ginjal kronik diawali oleh penyakit hipertensi, dimana penyakit ini dapat disebabkan karena gaya hidup yang tidak baik seperti merokok dan mengkonsumsi kafein, hipertensi yang berkepanjangan merupakan salah satu faktor resiko gagal ginjal kronik. Nurcahayati (2010).

$$
\text { Peneliti Yuliaw }
$$

mengemukkan bahwa bahwa jenis kelamin laki-laki mempunyai kualitas hidup lebih buruk dibandingkan perempuan. Hal ini disebabkan oleh perbedaan pekerjaan, kebiasaan hidup, dan genetik.

Menurut asumsi peneliti bahwa jenis kelamin tidak mempengaruhi kualitas hidup pasien gagal ginjal kronik (GGK) yang menjalani terapi hemodialisa di RSU Royal Prima Medan tahun 2019. Hal ini disebebkan karena setiap penyakit menyerang siapa saja baik laki-laki maupun perempuan.

\section{Hubungan pendidikan dengan} kualitas hidup pasien gagal ginjal kronik (GGK) yang menjalani terapi hemodialisa di RSU Royal Prima Medan Tahun 2019

Hasil penelitian dengan menggunakan uji chi-square maka didapat nilai $\mathrm{p}$ value $0,943>0,05$ yang berarti tidak ada hubungan pendidikan dengan kualitas hidup pasien gagal ginjal kronik (GGK) yang menjalani terapi hemodialisa di RSU Royal Prima Medan tahun 2019.

Salah satu faktor yang berhubungan dengan kualitas hidup adalah pendidikan, bahwa pada pasien yang berpendidikan rendah berisiko memiliki penyakit ginjal Suparti (2016).

Penelitian dilakukan oleh Fitri (2015) bahwa pendidikan mempengaruhi kualitas hidup pasien, pasien dengan tingkat pendidikan yang lebih rendah memiliki kualitas hidup yang lebih buruk dibandingkan dengan pasien berpendidikan tinggi, karena tingkat pendidikan mempengaruhi tingkat kesadaran seseorang terhadap kesehatan.
Penelitian ini sejalan dengan Ahmad (2018) bahwakualitas hidup pasien gagal ginjal kronik tidak dipengaruhi dari tingkat pendidikan karena dapat disebakan dari faktor lain baik dari segi demografi, biomedis, mau pun psikososial.

Menurut asumsi peneliti bahwa pendidikan tidak mempengaruhi kualitas hidup pasien gagal ginjal kronik (GGK) yang menjalani terapi hemodialisa di RSU Royal Prima Medan Tahun 2019. Setiap penyakit menyerang dari berbagai golongan pendidikan dan semakin rendah tingkat pendidikan pasien makan akan berpengaruh terhadap kualitas hidupnya.

\section{Hubungan lamanya hemodialisa} dengan kualitas hidup pasien gagal ginjal kronik (GGK) yang menjalani terapi hemodialisa di RSU Royal Prima Medan Tahun 2019.

Hasil penelitian dengan menggunakan uji chi-square maka didapat nilai $\mathrm{p}$ value $0,001<0,05$ yang berarti ada hubungan lamanya hemodialisa dengan kualitas hidup pasien gagal ginjal kronik (GGK) yang menjalani terapi hemodialisa di RSU Royal Prima Medan Tahun 2019.

Menurut peneliti Deddy (2015) bahwa semakin lama penderita menjalani hemodialisa maka penderita gagal ginjal kronik (GGK) semakin dapat beradaptasi dengan segala aktivitas-aktivitas rutin yang dijalaninya sehingga hal tersebut akan mendukung kualitas hidup pasien gagal ginjal kronik (GGK).

Hal ini sejalan dengan penelitian yang dilakukan Nurcahayti (2010) bahwa semakin lama responden manjalani hemodialisa maka responden akan semakin patuh untuk menjalani terapi hemodialisa karena pada tahap ini responden telah mencapai tahap menerima dan ditambah responden juga mendapatkan pengetahuan pendidikan kesehatan dari perawat atau pun dokter tentang penyakitnya dan pentingnya melaksanakan hemodialisa secara teratur.

Menurut asumsi peneliti bahwa lamanya hemodialisa merupakan salah satu faktor yang sangat mempengaruhi kualitas hidup pasien gagal ginjal kronik (GGK) yang menjalani terapi hemodialisa di RSU Royal Prima Medan tahun 2019, karena 
lamanya hemodialisa membuat pasien semakin memahami pentingnya kepatuhan terhadap proses hemodialisa sehingga pasien dapat merasakan manfaat dari terapi hemodialisa.

\section{KESIMPULAN}

Berdasarkan hasil penelitian dan pembahasan yang telah diuraikan sebelumnya mengenai faktor-faktor yang mempengaruhi kualitas hidup pasien gagal ginjal kronik (GGK) yang menjalani terapi hemodialisa di RSURoyal Prima Medan tahun 2019 dengan jumlah responden 70 orang, maka diperoleh satu kesimpulan yaitu:

1. Tidak ada hubungan umur dengan kualitas hidup pasien gagal ginjal kronik (GGK) yang menjalani terapi hemodialisa di RSU Royal Prima Medan tahun 2019.

2. Tidak ada hubungan jenis kelamin dengan kualitas hidup pasien gagal ginjal kronik (GGK) yang menjalani terapi hemodialisa di RSU Royal Prima Medan tahun 2019.

3. Tidak ada hubungan pendidikan dengan kualitas hidup pasien gagal ginjal kronik (GGK) yang menjalani terapi hemodialisa di RSU Royal Prima Medan tahun 2019.

4. Ada hubungan lamanya hemodialisa dengan kualitas hidup pasien gagal ginjal kronik (GGK) yang menjalani terapi hemodialisa di RSU Royal Prima Medan tahun 2019.

\section{SARAN}

Diharapkan pasien dapat melaksanakan terapi hemodialisa secara teratur agar tercapai kualitas hidup yang baik.

\section{DAFTAR PUSTAKA}

Arikunto, S. 2010. Metodologi Penelitian kesehatan. Jakarta: Rineka Cipta.

Avis, N. 2005. Assessing Quality of Life in Adult Cancer Survivors (QLACS). Diunduh dari http://www. wfubmc.edu pada tanggal 11 Maret 2019.

Bosniawan, Ahmad Miftakhul A. 2018. Faktor-Faktor Yang Mempengaruhi
Pada Kualitas hidup Penderita Gagal Ginjal Kronik di RSUD Sukoharjo. Surakarta: SKRIPSI.

Brunner \& Suddarth. 2002. Buku AjarKeperawatan Medikal Bedah. Jakarta:EGC.

Hay, R.D. 2010. The Medical Outcomes Study (MOS): Meansuring Functioning and Wellbeing. URL : http://www.rang.org

Kemenkes (Kementerian Kesehatan Republik Indonesia). 2018. Cegah dan Kendalikan Penyakit Ginjal Dengan Cerdik dan Patuh.

http://www.depkes.go.id/article/view/ $\underline{18030700007 / \text { cegah-dan-kendalikan- }}$ penyakit-ginjal-dengan-cerdik-danpatuh.html, diakses pada 13 Maret 2019.

Muhammad, As'adi. 2012. Serba-serbi Gagal Ginjal. Yogjakarta: Diva Press.

Nofitri, NFM. 2009. Gambaran Kualitas Hidup Penduduk Dewasa Pada Lima Wilayah di Jakarta. SKRIPSI.

Notoatmodjo,S. 2012. Metodologi Penelitian Kesehatan. Jakarta: Rineka Cipta.

Nurcahayati S. 2010. Analisis FaktorFaktor yang berhubungan dengan kualitas hidup pasien penyakit ginjal kronik yang menjalani hemodialisa di Rumah Sakit Islam Fatimah Cilacap dan Rumah Sakit Umum Daerah Banyumas. Depok: Tesis Universitas Indonseia.

Riskesdas (Riset Kesehatan Dasar). 2013. Badan Penelitian dan Pengembangan Kesehatan Kementerian Kesehatan RI. Jakarta: Departemen Kesehetan Republik Indonesia.

R, Handi., Tranado,H., \&Pransasti, T. 2018. Faktor-faktor Yang Mempengaruhi Kualitas Hidup Pasien Chronic Kidney Disease (CKD)Yang Menjalani Hemodialisa di Ruang Hemodialisa.

https://ipm2kpe.or.id/journal/index.p $\mathrm{hp} / \mathrm{JKS} /$ article/view/8/43diakses pada 15 Maret 2019.

Sagala, D. 2015. Analisa Faktor-Faktor Yang Mempengaruhi KualitasHidup Pasien Gagal Ginjal Kronik 
YangMenjalani Hemodialisa Di RumahSakit Umum PusatHaji Adam Malik Medan.http://ojs.stikesimelda.ac.id/index.php/jilki/article/vi ew/128. diakses pada 15 Maret 2019.

Suparti, Sri., dan Solikhah, Umi. 2016. Perbedaan Kualitas Hidup Pasien Gagal Ginjal Kronik Ditinjau Dari Tingkat Pendidikan, Frekuensi dan Lama Hemodialisis Di RSUD Goeteng Taroenadibrata Purbalingga. Jurnal: Medisains.

Saragih, D. 2010. Hubungan Dukungan Keluarga dengan Kualitas Hidup Pasien Gagal Ginjal Kronis yang Menjalani Terapi Hemodialisa di RSUP Haji Adam Malik Medan. http://repository.usu.ac.id/handle/123 456789/20218diakses pada11 Maret 2019.
Suhud, M. 2005. Cuci darah demi Kualitas hidup. Kompas Syb.

Supriyadi., Wangiyo., \& Sekar R Widowati. 2011. Tingkat Kualitas Hidup Pasien Gagal Ginjal Kronik Terapi Hemodialisis.Jurnal kesehatan Masyarakat (KEMAS) ISSN 18581196.

Whoqol-Bref. 2004. The World Health Organization Quality of Life (Whoqol)-Bref. https://www.who.int/ substance abuse/research tools/en/in donesian whoqol.pdf. diakses pada 15 Maret 2019.

Widyastuti, R. 2014. Korelasi lamamenjalani hemodialisis dengan indeks massatubuh pasien gagal ginjal kronik di RSUDArifin Achmad

ProvinsiRiau.https://jom.unri.ac.id/in dex.php/JOMFDOK/article/view/285 6/2770 diakses pada 11 Maret 2019. 